REPORTS OF MORPHOLOGY
$\begin{gathered}\text { Official Journal of the Scientific Society of Anatomists, } \\ \text { Histologists, Embryologists and Topographic Anatomists } \\ \text { of Ukraine } \\ \text { journal homepage: https://morphology-journal.com }\end{gathered}$

\title{
Fractal dimension of phylogenetically different parts of the human cerebellum (magnetic resonance imaging study)
}

Maryenko N.I., Stepanenko O.Yu.

Kharkiv National Medical University, Kharkiv, Ukraine

ARTICLE INFO

Received: 29 July, 2020

Accepted: 3 September, 2020

UDC: $611: 57.086: 517: 530.191$

CORRESPONDING AUTHOR

e-mail: maryenko.n@gmail.com Maryenko N.I.

\begin{abstract}
In recent years, fractal analysis has been increasingly used as a morphometric method, which allows to assess the complexity of the organization of quasi-fractal biological structures, including the cerebellum. The aim of the study was to determine the value of fractal dimension of phylogenetically different parts of the cerebellum by studying magnetic resonance imaging of the brain using the method of pixel dilation and to identify gender and age characteristics of individual variability of fractal dimension of the cerebellum and its external linear contour. The study was performed on the magnetic resonance images of the brain of 120 relatively healthy patients in age 18-86 years (65 women, 55 men). T2 weighted tomographic images were investigated. Fractal analysis was performed using the method of pixel dilation in the author's modification. Fractal dimension $(F D)$ values were determined for cerebellar tomographic images segmented with brightness values of 100 ( $\left.F D_{100}\right), 90$ (FD $)$ and in the range of 100-90 (FD ${ }_{100-90}$ or fractal dimension of the outer cerebellar contour) in its upper and lower lobes, which include phylogenetically different zones. The obtained data were processed using generally accepted statistical methods. The average value of $F D_{100}$ of the upper lobe of the cerebellum was $1.816 \pm 0.005$, the lower lobe $-1.855 \pm 0.005$. The average value of $F D_{90}$ of the upper lobe of the cerebellum was $1.734 \pm 009$, the lower lobe $-1.768 \pm 0.009$. The average value of $F D_{100-90}$ of the upper lobe of the cerebellum was $1.370 \pm 0.009$, the lower lobe - 1.431 \pm 0.008 . All three values of the fractal dimension of the lower lobe, which lobules have a lower phylogenetic age, are statistically significantly higher than the corresponding values of the fractal dimension of the upper lobe, have a more pronounced correlation with age than in the upper lobe. The developed research algorithm can be used to assess the condition of the cerebellum as an additional morphometric method during magnetic resonance imaging study of the brain.

Key words: fractal analysis, cerebellum, magnetic resonance imaging.
\end{abstract}

\section{Introduction}

Modern diagnostic methods of neuroimaging (CT, MRI and others) are the methods of choice for lifelong assessment of the morphofunctional state of various brain structures and the diagnosis of various pathological changes and diseases of the nervous system. Images of different brain structures obtained using these diagnostic methods allow to determine different qualitative characteristics (shape, individual anatomical features, the presence of foci of pathological changes, etc.) and quantitative characteristics (linear dimensions, area of different structures, brightness values, etc.). To determine the quantitative characteristics of brain structures on tomograms mainly use the methods of traditional morphometry, which allow to determine simple geometric characteristics - linear dimensions, area, volume $[5,7,9$, 10, 14].

Among the various structures of the CNS, the cerebellum has the most geometrically complex shape and spatial configuration, the cortex of which, forming its outer contour, forms a complex three-dimensional convoluted structure, which is difficult to quantify using morphometry methods commonly used to assess tomograms.

In recent years, fractal analysis has been increasingly used to assess complex branched biological structures. This method as a morphometric allows to estimate the degree of complexity of the organization and filling of space with quasi-fractal structures that have the properties of fractals - self-similarity, self-repetition and large-scale 
invariance. The value determined by fractal analysis is a fractal index or fractal dimension (FD), which can take values from 1 to $2[3,4]$.

Various modifications of fractal analysis are used to study the cerebellum and other CNS structures $[3,4,6,8$, $11,12,15-17,19-21]$, the most commonly used of which is the box counting method $[1,2,12,16,17,19,20]$ and pixel dilation method [11, 13].

In most works use fractal analysis to study different CNS structures with visual identification of the boundaries of the studied structures $[12,17]$ and skeletonization of images [11], which allows to determine the fractal dimension of skeleton images that correspond to the main branches of white matter. The cerebellum is a rather complex structure, so its fractal analysis must be multicomponent and take into account the study of various elements that can be identified using different image segmentation algorithms. In particular, in addition to skeletonization, you can use the determination of the fractal dimension of the external linear contour of the cerebellum and the fractal dimension of cerebellar tissue as a whole, which will objectively assess the morphofunctional state of the cerebellum by quantifying the complexity of the spatial configuration of its cortex. In addition, different anatomical areas of the cerebellum, which have different phylogenetic age, have some differences in structure [18], which in turn may affect the value of the fractal dimension and patterns of their variability.

The aim of the study was to determine the value of fractal dimension of phylogenetically different parts of the cerebellum by studying magnetic resonance imaging of the brain using pixel dilation and to identify sex and age characteristics of individual variability of fractal dimension of the cerebellum and its external linear contour.

\section{Materials and methods}

The study was performed on 120 magnetic resonance imaging of the brain of patients aged 18-86 years (mean age $-43.33 \pm 1.43$ years, 65 women, 55 men), in which no organic pathology of the brain was detected, so the structure of the brain of these patients were considered as a conditional norm.

The study was conducted in compliance with the basic bioethical provisions of the Council of Europe Convention on Human Rights and Biomedicine (04.04.1997), the Helsinki Declaration of the World Medical Association on the ethical principles of scientific medical research with human participation (1964-2008), and the order of Ministry of Health of Ukraine №690 dated 23.09.2009. The conclusion of the Commission on Ethics and Bioethics of Kharkiv National Medical University confirms that the study was conducted in compliance with human rights, in accordance with current legislation in Ukraine, meets international ethical requirements and does not violate ethical standards in science and standards of biomedical research (minutes of the meeting of the commission on ethics and bioethics of KhNMU №10 from 07.11.2018).

Tomograms were obtained using a magnetic resonance imaging Siemens Magnetom Symphony with a magnetic induction value of $1.5 \mathrm{~T}$. T2-weighted images were used for the study. The method of pixel dilatation in the author's modification described earlier was used for fractal analysis [13].

For fractal analysis, a fragment of a digital image of a tomogram containing a tomographic section of the cerebellum was copied and processed in Adobe Photoshop CS5. To study individual lobes from the image, $64 \times 64$ pixel sections corresponding to different phylogenetic and anatomical zones of the cerebellum were copied, namely: the upper lobe of the cerebellum, which includes the upper paleocerebellum (lobules I-V), the lower lobe of the cerebellum, which includes neocerebelum (lobules VI-VII), lower paleocerebellum with archicerebellum (lobules VIII-X) (Fig. 1A).

In order to separate the studied structure (cerebellar tissue) from the surrounding, background structures, image segmentation was performed. The image was transformed from halftone to binary format. The binary image consists of pixels of only two colors: black (which has a brightness value of 0 and corresponds to the studied structure) or white (has a brightness value of 255 and corresponds to the background pixels). Segmentation of cerebellar tissue in the image was performed using the tool "Threshold" of Adobe Photoshop CS5, which colors all pixels darker than the specified threshold value into black color, lighter - into white color (Fig. 1B).

For segmentation of tomographic sections of a cerebellum as a whole empirically established threshold value of brightness 100 (Fig. 1B). In order to investigate the outer contour of the cerebellum on a tomographic section, the brightness thresholds of 100 and 90 were empirically selected. Segmentation of digital tomographic images in this range (difference 100-90) allows to detect the outer linear contour of the cerebellum (Fig. 1D).

After segmentation, fractal analysis was performed using the pixel dilation method. To do this, the image resolution was gradually reduced from 64 pixels per inch to $32,16,8,4$, and 2 pixels per inch. In order to calculate the individual values of fractal dimension (FD) for the cerebellum as a whole and the contour separately, at each stage the number of segmented pixels corresponding to the studied structure was calculated for the threshold values of brightness $100\left(\mathrm{~N}_{1}\right)$ and $90\left(\mathrm{~N}_{2}\right)$ and their difference $\left(\mathrm{N}_{3}=\mathrm{N}_{1}-\mathrm{N}_{2}\right)$. The FD values calculated with the value of $\mathrm{N} 1$ correspond to the FD of the tomographic section of the cerebellum as a whole, $\mathrm{N}_{3}$ - FD contour of the cerebellar tissue.

FD values were determined for tomographic images of the cerebellum, segmented with brightness values 100 $\left(F D_{100}\right), 90\left(F D_{90}\right)$ and in the range of $100-90\left(F_{100-90}\right.$ or fractal dimension of the outer contour of the cerebellum) for its upper and lower lobes, including phylogenetically 


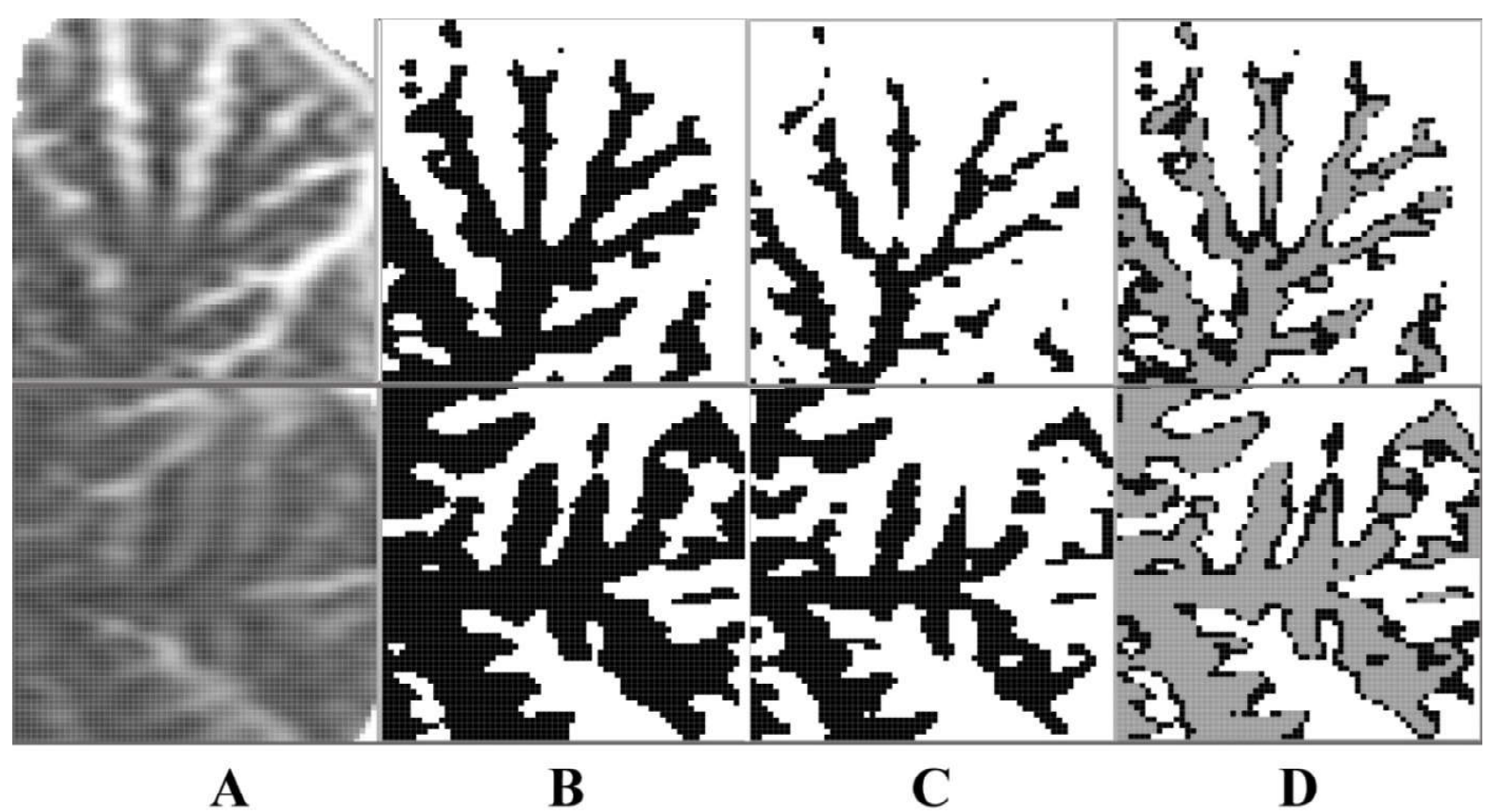

Fig. 1. Segmentation of digital image of magnetic resonance imaging of the human cerebellum. The upper row of images - upper lobe of the cerebellum, the lower row - lower lobe. A - the original image; B - segmentation with a threshold value of brightness $100, \mathrm{C}$ segmentation with a threshold value of brightness $90, \mathrm{D}$ - the difference between the thresholds 100 and 90 , which corresponds to the contour of the cerebellum, is shown in black color.

\section{different zones.}

Statistical data processing was performed using Microsoft Excel 2010. The following values were calculated: arithmetic mean $(M)$ and its error $\left(m_{M}\right)$. To determine the distribution of values, the median $(\mathrm{Me})$, the values of the 25th and 75th percentiles, the minimum (min) and maximum ( $\max$ ) values were determined. Pearson's correlation coefficient was calculated to determine the relationship between the values. The significance of statistical differences and the significance of the correlation were assessed using Student's $t$ test.

\section{Results}

The average value of $F D_{100}$ of the upper lobe of the cerebellum was $1.816 \pm 0.005$, the lower lobe $-1.855 \pm 0.005$. The average value of $F D_{90}$ of the upper lobe of the cerebellum was $1.734 \pm 0.009$, the lower lobe $-1.768 \pm 0.009$. The average value of $F D_{100-90}$ of the upper lobe of the cerebellum was $1.370 \pm 0.009$, the lower lobe $-1.431 \pm 0.008$. The distribution of fractal dimension values determined for the upper and lower lobes of the cerebellum is shown in Fig. 2.

The highest values are FD of tomographic sections of the cerebellum, segmented with a brightness threshold of $100\left(F_{100}\right)$, slightly lower - $90\left(F_{90}\right)$. The lowest value has FD of the outer contour of the cerebellum $\left(F_{100-90}\right)$.

$\mathrm{FD}_{100}$ has statistically significantly greater values than $F D_{90}$ and in the upper lobe of the cerebellum $\left(p=9.61 \mathrm{e}^{-14}\right)$, and in the lower lobe $\left(p=3.61 \mathrm{e}^{-15}\right)$, also has statistically significantly greater values than $\mathrm{FD}_{100-90}$ in both parts (upper lobe - $p=8.9 \mathrm{e}^{-113}$; lower lobe $-p=3.7 \mathrm{e}^{-117}$ ). In turn, $F D_{90}$ is statistically significantly higher than the value of $F_{100-90}$ in the upper $\left(p=1.98 e^{-78}\right)$ and lower $(p=6.98 e-77)$ lobes of the cerebellum.

All three values of FD of the lower lobe of the cerebellum, which corresponds to the phylogenetically younger areas of the cerebellum (neocerebellum and lower paleocerebellum), are statistically significantly higher than the corresponding values of FD of the lower lobe of the cerebellum, which corresponds to phylogenetically older areas (upper paleocerebelum) $\left(F D_{100}-p=1.23 e^{-7} ; F_{90}-\right.$ $\left.p=0.009 ; F D_{100-90}-p=1.27 e^{-6}\right)$. This feature generally reflects the peculiarities of the organization of cerebellar lobules at the micro-macroscopic level: lobules of neocerebellum and lower paleocerebellum, which have a smaller phylogenetic age, generally have a more complex spatial configuration due to more complex and diverse variants of structure and branching of white matter in these lobules, which patterns of individual anatomical variability have been described in our previous studies [18].

The calculated FD values $\left(F_{100}, F_{90}, F_{100-90}\right)$ are correlated by different strengths and orientations. Thus, $\mathrm{FD}_{100}$ is associated with $\mathrm{FD}_{90}$ by a strong positive correlation (upper lobe - $r=0.92, p=2.84 e^{-24}$; lower lobe - $r=0.96$, $\left.p=2.43 e^{-35}\right)$. But $F D_{100}$ is associated with $F D_{100-90}$ by negative correlation of weak force in the upper lobe $(r=-0.27, p=0.004)$ and negative correlation of medium force in the lower lobe $\left(r=-0.45, p=2.12 e^{-5}\right) . F D_{90}$ is also associated with $F D_{100-90}$ by 


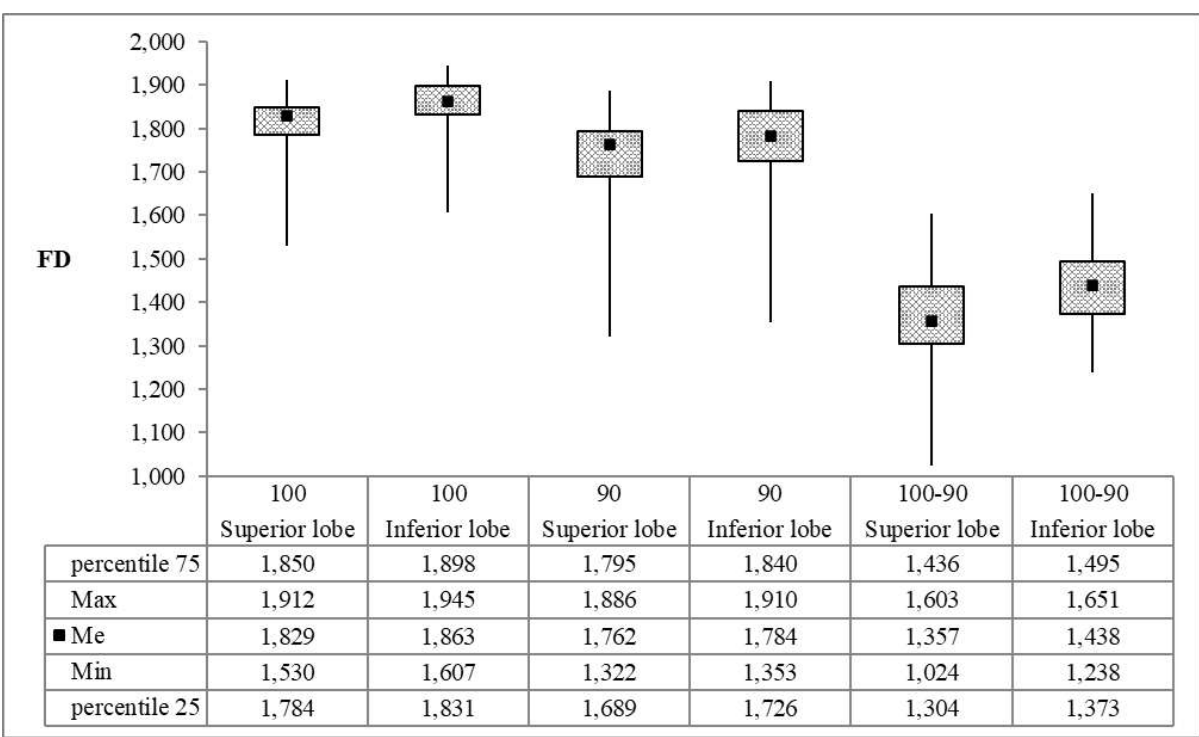

Fig. 2. Distribution of fractal dimension values $\left(\mathrm{FD}_{100}, \mathrm{FD}_{90}, \mathrm{FD}_{100-90}\right)$ of the upper and lower parts of the human cerebellum.

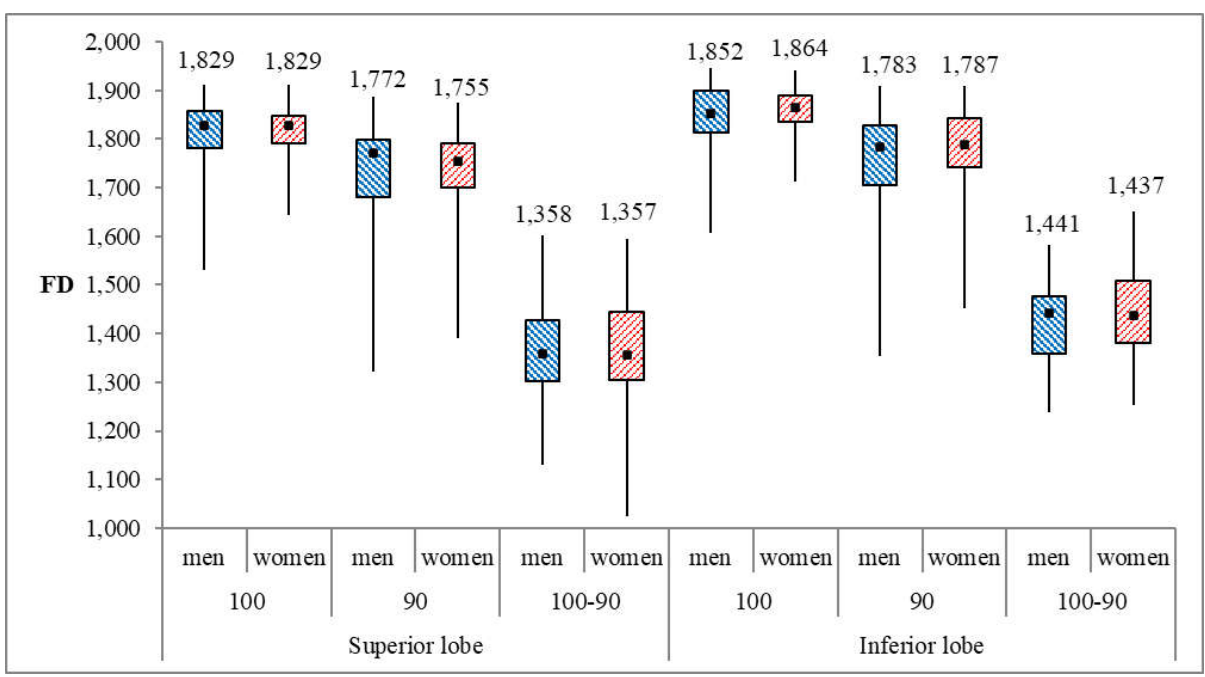

Fig. 3. Distribution of fractal dimension values $\left(\mathrm{FD}_{100}, \mathrm{FD}_{90}, \mathrm{FD}_{100-90}\right)$ of the upper and lower lobes of the human cerebellum in men and women.

negative correlation of medium strength in both parts of the cerebellum (upper lobe $-r=-0.57, p=2.41 e^{-7}$; lower lobe $\left.r=-0.65, p=5.34 \mathrm{e}^{-9}\right)$.

Paired values of the FD of the same name of the upper and lower lobes are related by a positive correlation $\left(\mathrm{FD}_{100}-\right.$ $r=0.76, p=3.26 e^{-12} ; F D_{90}-r=0.85, p=9.24 e^{-17} ; F D_{100-90}-r=0.83$, $p=1.87 e^{-15}$.

Sex characteristics were also determined: three FD values for the upper and lower lobes of the cerebellum in men and women were determined. The average value of $\mathrm{FD}^{100}$ of the upper lobe of the cerebellum in men was $1.815 \pm 0.006$, in women $-1.816 \pm 0.006$, the lower lobe in men $-1.847 \pm 0.009$, in women $-1.863 \pm 0.006$. The average value of $\mathrm{FD}^{90}$ of the upper lobe of the cerebellum in men was $1.734 \pm 0.014$, in women $-1.735 \pm 0.011$, the lower lobe in men $-1.759 \pm 0.015$, in women $-1.776 \pm 0.011$. The average value of $\mathrm{FD}_{100-90}$ of the upper lobe of the cerebellum in men was $1.366 \pm 0.012$, in women $1.372 \pm 0.013$, the lower lobe in men - $1.422 \pm 0.012$, in women $1.438 \pm 0.011$. The distribution of fractal dimension values $\left(\mathrm{FD}_{100}\right.$, $F D_{90}, F D_{100-90}$ ) in men and women is shown in Fig. 3.

Thus, the values of FD in men and women have almost no difference, statistically significant difference don't have all three fractal indices: $F D_{100}$ (upper lobe - $p=0.91$; lower lobe - $p=0.12$ ), $F D_{90}$ (upper lobe $p=0.99$; lower lobe $-p=0.34$ ) and $F_{100-90}$ (upper lobe - $p=0.74$; lower lobe - $p=0.32$ ), which indicates the absence of statistically significant sex differences in the studied indicators.

In addition to sex, the age features of variability of fractal dimension in different parts of the cerebellum were also studied (Fig. 4). It was found that $\mathrm{FD}_{100}$ has a positive correlation with age (upper lobe $-r=0.29$, $p=0.002$; lower lobe $-r=0,41$, $p=7,61 e-5$ ) as well as $F_{90}$ (upper lobe $-r=0.38, p=0.0001$; lower lobe $-r=0.50, p=3.75 e-6)$. In contrast to these indicators, $\mathrm{FD}_{100-90}$ has a negative correlation with age in both lobes (upper lobe $-r=-0.44$, $p=2.94 \mathrm{e}-5$; lower lobe $-r=-0.58$, $p=1.57 e-7)$. At the same time more expressed changes are observed in the lower lobe of a cerebellum (Fig. 3) which has smaller phylogenetic age.

$\mathrm{FD}_{100-90}$ characterizes the complexity of the organization of the outer contour of the cerebellum, which in turn characterizes the features of the spatial configuration of the cerebellar cortex. This figure decreases with age in both lobes of the cerebellum, which reflects the process of agerelated atrophy of the cerebellum, which is accompanied by a decrease in the degree of convoluting of the cortex, which leads to a decrease in the fractal index of the outer contour of the cerebellum. More pronounced age-related changes are observed in phylogenetically younger areas, which have higher values of fractal dimension in general (which reflects the more complex and diverse structure of these lobules). Thus, areas of the cerebellum that have a more complex spatial configuration of the cortex are characterized by a 


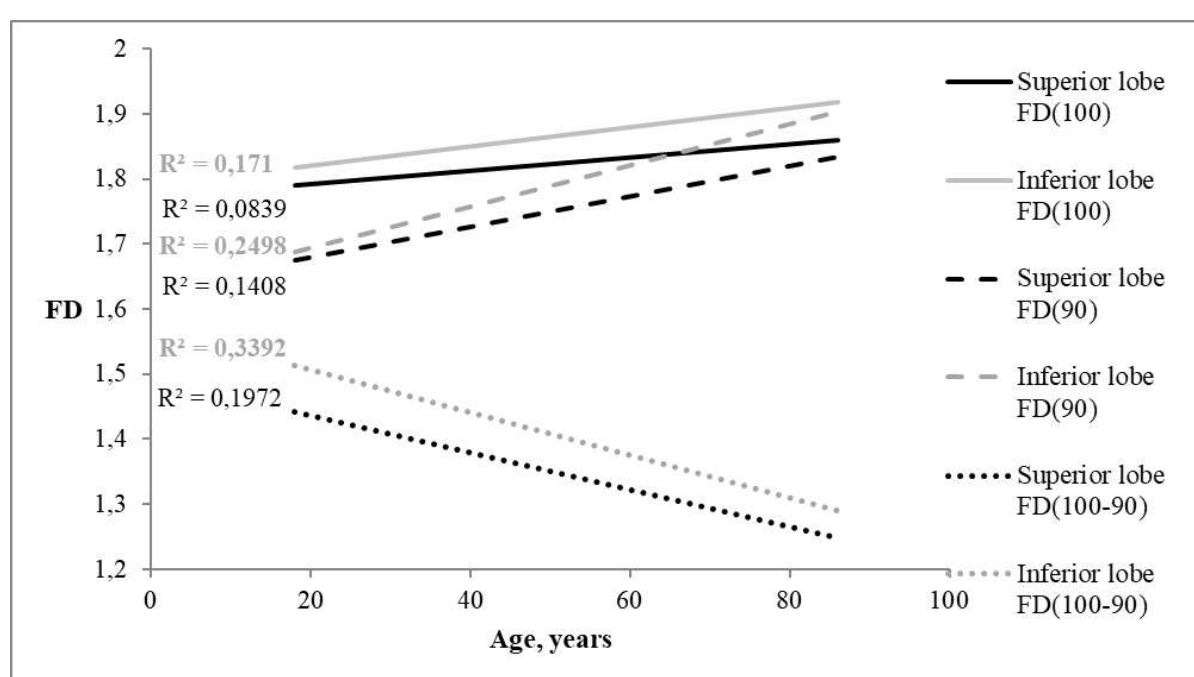

Fig. 4. Values of fractal dimension $\left(F D_{100}, F D_{90}, F D_{100-90}\right)$ of the upper and lower lobes of the cerebellum depending on age.

more pronounced decrease in the fractal index with age than areas that have a less complex structure and greater phylogenetic age.

It should be noted that the decrease in this indicator is more pronounced in men (upper lobe $-r=-0.54, p=8.24 e^{-6}$; lower lobe $-r=-0.67, p=1.76 e^{-8}$ ) than in women (upper lobe - $r=-0.37$, lower lobe $-p=0.002 ; r=-0.51, p=2.60 e^{-5}$ ), which reflects the more pronounced age-related atrophy of the cerebellum, characteristic for men.

\section{Discussion}

The values of the fractal dimension obtained in this study exceed the values of the fractal dimension obtained by us earlier in the study of sectional material $(1.372 \pm 0.006)$ [16]. This difference is due to the fact that in this study we determined the fractal dimension of tomographic sections of the cerebellum as a whole and its outer linear contour, while on the section material we determined the fractal dimension of the main branches of the white matter of the cerebellum.

Another values of the fractal dimension of the cerebellum have been obtained in the works of other scientists. The values of the fractal dimension of two-dimensional images of the cerebellum, calculated on MR tomograms of 16 relatively healthy patients using the method of counting squares, were $1.49 \pm 0.06$ and $1.56 \pm 0.05$ for white and gray matter, respectively [1]. In other works, three-dimensional values of fractal dimension were determined: three-

\section{References}

[1] Akar, E., Kara, S., Akdemir, H., \& Kiris, A. (2015). Fractal dimension analysis of cerebellum in Chiari Malformation type I. Computers in Biology and Medicine, 64, 179-186. https:// doi.org/10.1016/j.compbiomed.2015.06.024

[2] Akar, E., Kara, S., Akdemir, H., \& Kiris, A. (2017). 3D structural complexity analysis of cerebellum in Chiari malformation type I. Medical \& Biological Engineering \& Computing, 55(12), dimensional FD value of white matter was 2.26 \pm 0.05 [2] and $2.277 \pm 0.045$ [19], gray matter $2.49 \pm 0.04 \quad$ [2] and $2.5267 \pm 0.0228$ [19]. In these works, the FD values were determined using the method of counting squares. In another work [11], the values of FD of skeletonized branches of the cerebellar white matter were determined using one of the modifications of the pixel dilatation method. The value of the three-dimensional fractal dimension obtained as a result of this study was $2.57 \pm 0.01$. The difference between the average values of the fractal dimension obtained as a result of our and other studies can be explained by the peculiarities of the method of determining the fractal dimension and the differences of the cerebellar segmentation algorithm into different components of the structure and background.

Fractal analysis of magnetic resonance imaging of the brain can be used to diagnose the condition of the cerebellum as an additional morphometric study in magnetic resonance imaging of the brain. The obtained data and described research algorithms can be used for morphometric examination of the cerebellum using magnetic resonance imaging.

\section{Conclusions}

1. As a result of the study of magnetic resonance imaging of the brain with the help of the author's modification of the method of pixel dilatation, the value of the fractal dimension of tomographic sections of the cerebellum as a whole and its external linear contour was determined.

2. All three values of the fractal dimension $\left(\mathrm{FD}_{100}, \mathrm{FD}_{90}\right.$, $F D_{100-90}$ ) of the lower lobe, lobules of which have a lower phylogenetic age, statistically significantly exceed the corresponding values of the fractal dimension of the upper lobe and have a more pronounced correlation with age compared to the upper lobe. These features are consistent with the structure of the cerebellar lobules belonging to its lower lobe, and are characterized by a more complex and diverse structure than lobules belonging to the upper lobe of the cerebellum and have a greater phylogenetic age.

2169-2182. https://doi.org/10.1007/s11517-017-1661-7

[3] Di leva, A., Esteban, F. J., Grizzi, F., Klonowski, W., \& MartinLandrove, M. (2015). Fractals in the neurosciences, Part II: clinical applications and future perspectives. The Neuroscientist: a review journal bringing neurobiology, neurology and psychiatry, 21(1), 30-43. https://doi.org/10.1177/ 1073858413513928 
[4] Di leva, A., Grizzi, F., Jelinek, H., Pellionisz, A. J., \& Losa, G. A. (2014). Fractals in the Neurosciences, Part I: General Principles and Basic Neurosciences. The Neuroscientist: a review journal bringing neurobiology, neurology and psychiatry, 20(4), 403-417. https://doi.org/10.1177/ 1073858413513927

[5] Diedrichsen, J., Balsters, J. H., Flavell, J., Cussans, E., \& Ramnani, N. (2009). A probabilistic MR atlas of the human cerebellum. Neurolmage, 46(1), 39-46. https://doi.org/10.1016/ j.neuroimage.2009.01.045

[6] Grizzi, F., Castello, A., Qehajaj, D., Russo, C., \& Lopci, E. (2019). The Complexity and Fractal Geometry of Nuclear Medicine Images. Molecular Imaging and Biology, 21(3), 401-409. https:/ /doi.org/10.1007/s11307-018-1236-5

[7] He, N., Langley, J., Huddleston, D. E., Ling, H., Xu, H., Liu, C. ... $\mathrm{Hu}$, X. P. (2017). Improved Neuroimaging Atlas of the Dentate Nucleus. Cerebellum, 16(5-6), 951-956. https://doi.org/ 10.1007/s12311-017-0872-7

[8] John, A. M., Elfanagely, O., Ayala, C. A., Cohen, M., \& Prestigiacomo, C. J. (2015). The utility of fractal analysis in clinical neuroscience. Reviews in the Neurosciences, 26(6), 633-645. https://doi.org/10.1515/revneuro-2015-0011

[9] Lee, D. K., Yoon, U., Kwak, K., \& Lee, J. M. (2015). Automated Segmentation of Cerebellum Using Brain Mask and Partial Volume Estimation Map. Computational and Mathematical Methods in Medicine, 167489. https://doi.org/10.1155/2015/ 167489

[10] Lehman, V. T., Black, D. F., DeLone, D. R., Blezek, D. J., Kaufmann, T. J., Brinjikji, W., \& Welker, K. M. (2020). Current concepts of cross-sectional and functional anatomy of the cerebellum: a pictorial review and atlas. The British Journal of Radiology, 93(1106), 20190467. https://doi.org/10.1259/ bjr.20190467

[11] Liu, J. Z., Zhang, L. D., \& Yue, G. H. (2003). Fractal dimension in human cerebellum measured by magnetic resonance imaging. Biophysical Journal, 85(6), 4041-4046. https://doi.org/ 10.1016/S0006-3495(03)74817-6

[12] Liu, S., Fan, X., Zhang, C., Wang, Z., Li, S., Wang, Y. ... Jiang, T. (2019). MR imaging based fractal analysis for differentiating primary CNS lymphoma and glioblastoma. European Radiology, 29(3), 1348-1354. https://doi.org/10.1007/s00330-018-5658-x
[13] Maryenko, N. I., \& Stepanenko, O. Yu. (2019). Fractal analysis as a morphometric method in morphology: a pixel dilatation technique in the study of digital images of anatomical structures. Medicine Today and Tomorrow, 82(1), 8-14. https:/ /doi.org/10.35339/msz.2019.82.01.02

[14] Park, M. T., Pipitone, J., Baer, L. H., Winterburn, J. L., Shah, Y., Chavez, S. ... Chakravarty, M. M. (2014). Derivation of highresolution MRI atlases of the human cerebellum at $3 \mathrm{~T}$ and segmentation using multiple automatically generated templates. Neurolmage, 95, 217-231. https://doi.org/10.1016/ j.neuroimage.2014.03.037

[15] Ristanovic, D., \& Milosevic, N. T. (2012). Fractal analysis: methodologies for biomedical researchers. Theoretical Biology Forum, 105(2), 99-118.

[16] Smitha, K. A., Gupta, A. K., \& Jayasree, R. S. (2015). Fractal analysis: fractal dimension and lacunarity from MR images for differentiating the grades of glioma. Physics in Medicine and Biology, 60(17), 6937-6947. https://doi.org/10.1088/00319155/60/17/6937

[17] Stepanenko, A. Yu., \& Maryenko, N. I. (2017). Fractal analysis of the human cerebellum white matter. World of Medicine and Biology, 61(3), 145-149. https://doi.org/10.26724/2079-83342017-3-61-145-149

[18] Stepanenko, A. Yu., \& Maryenko, N. I. (2014). The variants of white matter branches structure of human cerebellum vermis. Bulletin of Problems in Biology and Medicine, 4(2), 259-264.

[19] Wu, Y. T., Shyu, K. K., Jao, C. W., Wang, Z. Y., Soong, B. W., Wu, H. M., \& Wang, P. S. (2010). Fractal dimension analysis for quantifying cerebellar morphological change of multiple system atrophy of the cerebellar type (MSA-C). Neurolmage, 49(1), 539-551. https://doi.org/10.1016/ j.neuroimage.2009.07.042

[20] Zaletel, I., Ristanovic, D., Stefanovic, B. D., \& Puskas, N. (2015). Modified Richardson's method versus the box-counting method in neuroscience. Journal of Neuroscience Methods, 242, 9396. https://doi.org/10.1016/j.jneumeth.2015.01.013

[21] Zhang, L., Liu, J. Z., Dean, D., Sahgal, V., \& Yue, G. H. (2006). A three-dimensional fractal analysis method for quantifying white matter structure in human brain. Journal of Neuroscience Methods, 150(2), 242-253. https://doi.org/10.1016/ j.jneumeth.2005.06.021

\section{ФРАКТАЛЬНА РОЗМІРНІСТЬ ФІЛОГЕНЕТИЧНО РІЗНИХ ДІЛЯНОК МОЗОЧКА ЛЮДИНИ (ЗА ДАНИМИ ДОСЛІДЖЕННЯ МАГНITHО-РЕЗОНАНСНИХ ТОМОГРАМ) Мар'єнко H.І., Степаненко О.Ю.}

Фрактальний аналіз в останні роки все частіше використовують у якості морфометричного методу, що дозволяє оцінювати ступінь складності організації квазифрактальних біологічних структур, у тому числі й мозочка. Мета дослідження - визначити значення фрактальної розмірності фрілогенетично різних ділянок мозочка шляхом дослідження магнітно-резонансних томограм головного мозку за допомогою методу дилатації пікселів та виявити гендерні та вікові особливості індивідуальної мінливості фрактальної розмірності мозочка та його зовнішнього лінійного контуру. Дослідження проведене на 120 магнітнорезонансних томограмах головного мозку умовно здорових пацієнтів віком 18-86 років (65 жінок, 55 чоловіків). Досліджені Т2 зважені томографічні зображення. Проведений фрактальний аналіз за допомогою методу дилатації пікселів у авторській модифікації. Визначались значення фрактальної розмірності (FD) для томографрічних зображень мозочка, сегментованих зі значеннями яскравості 100 (FD 100 ), 90 (FD ( $_{90}$ та у діапазоні 100-90 (FD мозочка) для його верхньої та нижньої часток, що включають фрілогенетично різні зони. Отримані дані обробляли за допомогою загальноприйнятих статистичних методів. Середнє значення $F D_{100}$ верхньої частки мозочка становило

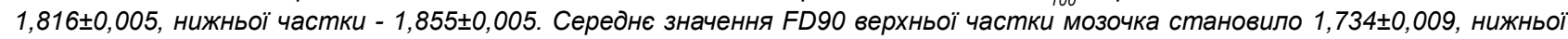

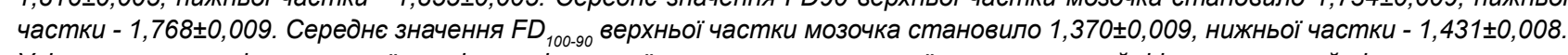
Усі три значення фррактальної розмірності нижньої частки, часточки якої мають менший фрілогенетичний вік, статистично значуще перевищують відповідні їм значення фрактальної розмірності верхньої частки, мають більш виражений кореляційний зв'язок із віком порівняно з верхньою часткою. Розроблений алгоритм дослідження може бути використаний для діагностики стану мозочка в якості додаткового морфометричного дослідження при проведенні магнітно-резонансної томографії головного мозку. 
Ключові слова: фррактальний аналіз, мозочок, магнітно-резонансна томографія.

\section{ФРАКТАЛЬНАЯ РАЗМЕРНОСТЬ ФИЛОГЕНЕТИЧЕСКИ РАЗЛИЧНЫХ УЧАСТКОВ МОЗЖЕЧКА ЧЕЛОВЕКА (ПО ДАННЫМ ИССЛЕДОВАНИЯ МАГНИТНО-РЕЗОНАНСНЫХ ТОМОГРАММ) \\ Марьенко Н.И., Степаненко А.Ю.}

Фрактальный анализ в последние годы все чаще используют в качестве морфометрического метода, позволяющего оценивать степень сложности организации квазифрактальных биологических структур, в том числе и мозжечка. Цель исследования - определить значение фррактальной размерности фрилогенетически различных участков мозжечка путем исследования магнитно-резонансных томограмм головного мозга с помощью метода дилатации пикселей и выявить гендерные и возрастные особенности индивидуальной изменчивости фрактальной размерности мозжечка и его внешнего линейного контура. Исследование проведено на 120 магнитно-резонансных томограммах головного мозга условно здоровых пациентов в возрасте 18-86 лет (65 женщин, 55 мужчин). Исследованы Т2 взвешенные томографические изображения. Проведен фррактальный анализ с помощью метода дилатации пикселей в авторской модификации. Определены значения фррактальной размерности (FD) для томографических изображений мозжечка, сегментированных со значениями яркости $100\left(F D_{100}\right), 90\left(F D_{90}\right)$ и в диапазоне 100-90 ( $F D_{100-90}$ или фррактальная размерность внешнего контура мозжечка) для его верхней и нижней долей, включающих фрилогенетически различные зоны. Полученные данные обрабатывали с помощью общепринятых статистических методов. Среднее значение $F D_{100}$ верхней доли мозжечка составило $1,816 \pm 0,005$, нижней

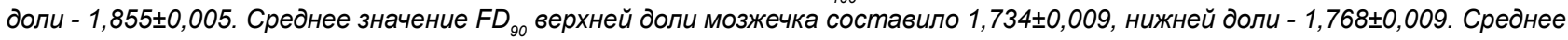

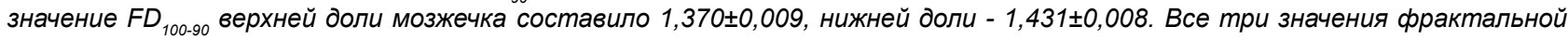
размерности нижней доли, дольки которой имеют меньший филогенетический возраст, статистически значимо превышают соответствующие им значения фррактальной размерности верхней доли, с возрастом имеют более выраженную корреляционную связь по сравнению с верхней долей. Разработанный алгоритм исследования может быть использован для диагностики состояния мозжечка в качестве дополнительного морфометрического исследования при проведении магнитно-резонансной томографрии головного мозга.

Ключевые слова: фррактальный анализ, мозжечок, магнитно-резонансная томографрия. 